\title{
Natural ester fluids applications in transformers as a sustainable dielectric and coolant
}

Hernan Hernandez-Herrera, Jorge I. Silva-Ortega, Mario Mejia-Taboada, Alfredo Diaz Jacome, and Melissa Torregroza-Rosas

DOI:

https://doi.org/10.1063/1.5116976

Abstract:

New requirements for a better sustainable energy policy around the world is easy to observe, many projects in sustainable energy are developed wherein the academia works together the authorities and commercial firms such as electrical grid utilities. In distribution transformers one of the suggested solutions is to replace mineral oils used as dielectric and coolant for natural ester fluids, they provide improved technical properties making them a safe substitute of mineral oil. Natural esters are based on clean technology in order to guarantee requirements from utilities. The main goal of the present paper is to present a technical-economic analysis obtained from five years of applications of oil-immersed transformers using natural ester fluids in Colombia. The methodology considers forty-four oil-immersed distribution Transformers, a half use mineral oil and the other side use natural ester, operating under the same load regime. Results evidenced the feasibility of implementing this technology because the costs are very similar and the reduction of risks and environmental impact is considerable. (c) 2019 Author(s).

\section{Keywords:}

Distribution transformers, Mineral Oil, Natural ester fluids, safety operation in power distribution system 